\title{
On Natural Value Theory of Physiocracy: A Perspective of Marx's Ecological Economics
}

\author{
Chen Anqi \\ School of Marxism, Shenyang Jianzhu University \\ Shenyang, China, 110168 \\ 2042734984@qq.com
}

\author{
Ren Qiaohua \\ School of Marxism, Shenyang Jianzhu University \\ Shenyang, China, 110168 \\ tony805@163.com
}

\begin{abstract}
The natural value theory of physiocracy indicates that the raw materials produced by the land are sources of wealth and economic value. However, the physiocrats fail to fully consider the relationships among the use-value, the capitalist production relationship and market values, and distinguish them from the value of capitalism. This paper, based on Marx's viewpoint, criticizes the natural values of physiocracy in terms of natural value and surplus-value, the tension between monetary form and natural environment, and ecological assessment methodology. It also provides a viable framework for the analysis of the deadlock from this ecological assessment.
\end{abstract}

Keywords-Physiocrats; Natural value theory; Marx; Ecological Economics; Ecological assessment

\section{INTRODUCTION}

Anthropocentrism is often centered on human beings, believing that resources are inexhaustible. Therefore, mankind's wild plunder on ecological resources has caused ecological deterioration. This view of nature has been strongly criticized that it stimulates related disciplines to spring up everywhere, including ecological economics. Pual Burkett, one of the founders of ecological economics, constructs the ecological economic value theory from the perspective of multidisciplinary and methodology of ecological economics. In his point, there are two diametrically opposed ecological economic values. One concern is that value is ascribed to natural resources, indicating that the monetary exchange-values generally represents the value derived from nature. Another concern is nature, and particularly the objective conditions or foundations for the value of low entropy matter and energy will be considered as "enjoyment of life". However, how to resolve this controversial value position? How does Burkett explain the opposition of this position from the critical theory of Marxism? The answers to these questions are of crucial importance to the study of ecological economics.

\section{The ORIGIN OF THE PhysiocRATs NATURAL VALUE}

\section{A. Debate about the direct source of value by Ecological economists}

Eco-economists, represented by Robert Costanza, and Nicholas Georgescu-Roegen, focus on the role of human production in limited natural conditions. In contrast to advocating protecting the personal interests and emphasizing the privatization of neoclassical economics, they place more emphasis on unproductive resources that are irreplaceable by manpower and technology. The resulting debate is: is it most logical to ascribe value to natural resources directly?

1) Regard natural resources as a direct source of value

This standpoint is guided by the "embodied-energy" theorist, represented by Costanza (1981), who argues that "primary input" in production is energy [1]. In this sense, energy is of significance in production inputs and the production and service of commodities also require "gratis" or "available" energy, so energy is seen as a very important factor of production, and the wealth that capitalism obtains from nature exceeds the capital it has invested. It makes the value transfer from resources to profit also. In short, the theory of embodied-energy is actually a theory of production costs, and all the costs return directly and indirectly in the solar energy they need.

2) Natural resources as a basic condition for enhancing the commodity value and services

Instead of treating natural resources as direct sources of value, eco-economists Georgescu-Roegen (1979) defined natural resources as the basis for "enjoyment of life" by applying the thermodynamics [2]. For them, the value of any production stems from the satisfaction of human needs and expectations, even though the final product must be adjusted to its production costs. Therefore, Georgescu-Roegen did not define the priority of any one or a few factors of production. 


\section{B. From the theory of entropy to the theory of physiocrats economic value}

In general, matter and energy have undergone a process from order to disorder, all of which are related to production, while production involves matter and energy from a more ordered to a less ordered. Therefore, the final usable mater in social production is the low-entropy matter-energy, that is, low energy consumption and low pollution. Low-entropy matterenergy exists in two forms: land reserves and solar energy. Therefore, the low-entropy matter-energy becomes the final input and limit of production, indicating that at a certain time, the production must adapt to a relatively stable state so as to ensure its own reproducibility.

\section{1) The question about the form of the capitalist production} system

Georgescu-Roegen (1979) realized that the economic form of a supply system can not simply be reduced to a purely physical, entropy form. [2] He believes that production can not be expressed by a large thermodynamic equation. Alternative low entropy energy sources differ greatly in the appropriateness of different substances and energy conversions required for human production and consumption [3]. In their view, the value of any production stems from the satisfaction of human needs and expectations. Therefore, production of reality products does not reflect the flow of mater and energy, but "enjoyment of life," and low-entropy matter-energy and purposeful human labor are the basic prerequisites.

\section{2) Physiocrats'Views on Natural Values}

As one of the representatives in the field of modern ecological economics, Burkett(2006)states that physiocrats represents a view on the difference of natural values by modern ecological economists.[4] He maintains the physiocrats who regard nature as a direct source of economic value and the surplus derived from land as the main driving force of wealth production. This view is consistent with the energy theory of value and the Georgescu-Roegen "enjoyment of life" theory, found the final net input of energy and low-entropy matterenergy.

\section{3) Low-entropy material energy and "enjoyment of life"}

Georgescu-Roegen (1979) consider the low-entropy material energy as a necessary condition for spiritual income or the "enjoyment of life." [2] On this basis, they refuse to directly view natural value as production cost. Although low entropy is a necessary condition for the value of things, it does not fully explain the value of one kind of goods relative to another. Georgescu-Roegen similarly failed to relate the question of nature valuation to the capitalist production relations. The naturalization of this market relationship has led to the possibility of a division between allocation and scale. Although Georgescu-Roegen pointed out the necessary ecological and cultural foundations for "enjoyment of life," they did not provide alternatives to the neoclassical value theory.
Since eco-economists represented by Georgescu-Roegen failed to analyze the value of natural resources by using energy as the center of ecological economics, Therefore, the physiocrats theory of natural value was developed in the debate whether the direct assignment of natural resources to values is the most logical one.

\section{The CONNOTATION OF THE PHYSIOCRATS NATURAL VALUE THEORY}

\section{A. Implications of the Physiocrats natural value theory}

Physiocrats see the raw material produced on the land as a source of real wealth and economic value. As Turgot (1898) said, "Earth is always the first and only source of all wealth." [5]From this perspective, land is a net product of means of subsistence for the production of material life, and a means for agricultural labourers to make a living. Meanwhile agricultural production relies on human labor and intelligence, these net products are the natural result of soil fertility and agricultural labourer intelligence.

Most economists believe that physiocracy represents only a kind of historical contingency. In the controversy of the natural values, thermodynamics and energy value theory dominate the leading position, thus physiocracy is to be marginalized. In fact, the development of physiocracy preceded the laws of thermodynamics, and this helped to explain ecological value analysis. Georgescu-Roegen (1979) portrayed the doctrine of physiocracy as an "analytico-physiological approach" in an attempt to link economic phenomena with biological physiological analysis [2]. But he did not relate this methodology to the question of the value of nature. Similarly, in Burkett's view, the value theory of physiocracy is based on the unique ability of land to produce the means of subsistence that people need. For the physiocrats, non-agricultural production involves the increased use of the means of material life created by agriculture, and agriculture can "generation or creation of wealth."

Burkett ( 2006 ) argues that the physiocrats treat agricultural labor as the prime mover behind the order of division of labor among the different members of society [4]. This is a "primacy of physical necessity," where the means of material subsistence of non-agricultural labor depends on the "surplus" of means of subsistence produced by agricultural laborers. From the basic point of view of wealth production, he divided the social division of labor into the productive class, the owner and the non-productive class. The productive class regenerates the wealth of the land by cultivating the land, and the landowner exists as the cultivated income or net product. The non-productive class is composed of all citizens who are engaged in production or service as compared with the productive class, the cost is paid by the production class and the owner class, the production class is its source of income. 


\section{B. Physiocrat nature value theory purport}

The physiocrats conducted a materialist analysis of capitalist production, and held that the value of the natural material use-value recognition brought about the naturalization of capitalist value forms and the issue of class relations. From the perspective of capitalist relations of production, Burkett (2006) pointed out that the physiocrats considered the capitalist relations of production as natural, and therefore the physiocrats did not analyze the connection between these relations and the capitalist wealth valuation [4]. Therefore, in their system, value itself is simply attributed to pure use-value. The physiocrats viewed the "agricultural labour" as "the creator of surplus-value," and they emphasized the concept of nature's gift and the natural basis of surplus-value, and used the concepts of capitalism to discuss it.

The physiocrats natural value theory is focused upon agricultural production, and indicated that capital can be invested in there, so that it can develop into a large capitalization of agriculture and strengthen the development of agriculture. Ecological economists also pay attention to physiocracy, but they do not root the problem of natural values in capitalist basic production relations. They free the labor force from the land and other necessary production conditions, and unify the labor force and production conditions, only as the merchandise that wage-labour and produces capital to make profits. In this sense, the ecological assessment debate does not regard natural monetary valuation as a specific form of capitalist valuation. This is also the limitation of physiocratic natural value theory.

\section{The Limitations Of Physiocratic NATURAL VAlue THEORY}

For physiocrats, the essence of value is the composition of land, nature, and various changes in these substances. Although physiocrat natural value theory promotes the development of agriculture on a certain basis, it establishes an important position for agriculture in the socio-economic development of capitalism. However, because the physiocrats just focuses on agricultural production, it is bound to have some limitations :

\section{1) The "metabolic fault" between humans and nature}

The physiocrats did not solve the qualitative problems brought about by the marketization and monetization of general wealth and natural wealth. They did not delve into the intrinsic relationship between capitalist production relations and capitalist values, that is, the basic valuation of capitalism form which from the "metabolic rift" between man and nature that JB Foster (2000)proposes.[6]57

2) The confusion between natural value and capitalist "value"

Physiocrats conflate natural values with the "value" of capitalism. Burkett pointed out that the physiocrats failed to dialectically analyze the forms of capitalist wealth valuation [4]. In other words, the physiocrats failed to analyze the "value" under specific social relations conditions from the perspective of history. This led to physiocrats confusing the natural value of real wealth with the "value" of capitalism. Because physiocrats regard capitalist relations of production as natural (at least in agriculture), they do not analyze the connection between these relations and the specific form of capitalist valuation of wealth. Therefore, in their system, value itself is simply attributed to pure use-value. In other words, the physiocrats regard exchange value and money as natural forms of wealth or use-value.

\section{3) The physiocrats's surplus-value problem}

The physiocrats' limited historical vision of society has prevented them from critically analysing the specific forms of capitalist valuation and exploitation of wealth, and attributes surplus-value to a purely natural basis. For Marx, physiocrats are new capitalists that prevail in the feudal society [7]. Therefore, the capitalist form of production inherent in the physiocrats is an eternal, natural form of production, and it is the means of the feudal system of the bourgeoisie to reproduce and rule the land property.

The physiocrats did not reveal the mystery of how capitalists extract surplus value. For Marx, the source of surplus-value is the value created by the worker's surplus-labor, which is the labor time beyond the necessary labor time [7]. However, the physiocrats believe that there is a precondition for the generation of surplus-value. That is, in agricultural production, agricultural laborers produce more production and living materials than they need to be able to satisfy the survival of non-agricultural laborers. Otherwise, agriculture has no surplus-products, non-agricultural workers have no livelihoods, and therefore there is no surplus-value. So, for farmers, agricultural labor is the only productive labor. However, the values of physiocrats and material wealth do not shed light on their relationship with the amount of labor or labor time, nor reveal the mystery of the capitalists' pursuit of surplus-value. This, in turn, explains why they cannot realize the true mystery of surplus value.

\section{MARX'S SUblation OF PHYSIOCRACY THOUGHT}

Different from the rustic methodology of physiocrats, the Marxist ecological economic theory critically examines the relationship between concepts of physiocracy and capitalist analysis. In physiocrats doctrine, Marx recognized that if there is no agricultural surplus, there will be no agricultural surplus labor force and no means of non-agricultural laborer's survival, so there will be no surplus-value in the entire economy. But it is worth noting that Marx pointed out that the physiocrats accepted the capitalist relations of production uncritically, at least in the agricultural sector [7]. The main reason for this defect is that the physiocrats attribute the decision of surplusvalue to nature.This is also the only difference between Marx and the Physiocrats in the theory of surplus value, and a rejection of the ideology of gratitude. From the perspective of Marx's criticism of physiocracy, the capitalization of natural value is the condition and result about the alienation of the real wealth for the direct producer by the capitalist system, and Marx from five perspectives inherited physiocracy thought mature thought and criticized the corresponding defects. 


\section{A. Marx's Critique of physiocratic conceptions of nature's "gifts"}

Marx, like physiocrats, often refers to natural production conditions as natural "gifts," and these gifts can be freely occupied by capitalism [7]. The gift of nature becomes a free capital "gift." Even if they are not the product of wage-labour, natural resources also provide the use-value of production and realization of surplus-value. Therefore, Marx believes that the free possession of natural gifts is an important condition for the development of capitalism. At the same time, he also recognizes the indispensable position of natural gifts in the capitalist relations of production.

Unlike the physiocratism theory is, in Marx's view, the condition for capitalism to convert natural gifts into surplusvalue production is that the labor force separates from the land and other necessary production conditions. Therefore, Marx's critique of physiocracy shows that the capitalization of nature's "gift" is the condition and result of the alienation of the real wealth of the direct producers by the capitalist system.

\section{B. Criticize the concept of physiocracy values}

In the debate between physiocracy and the evaluation of contemporary natural values, Marx defines "value" as a concrete form of capitalist economic assessment [7]. Physiocrats emphasizes that value is transformed from material production. In Marx's view, capitalism restores economic value to abstract, homogeneous socially necessary labor time. For him, use-value is anything that meets human needs, and value is a concrete social representation of capitalist use-value. In this system, use-value is an important factor in the exchange of goods. Therefore, Marx pointed out that the close relations between the use-value and the exchange value should be analyzed with the specific production relations of capitalism.

For Marx, capitalism links value with socially necessary labor time. Social production is mainly organized through the competition of the enterprise that employs labor as a profit object. Therefore, in terms of real wealth or use-value, nature and labor are equally important. It can thus be seen that Marx did not regard abstract labor time as a proper representation or measure of wealth, including natural wealth. In fact, Marx does not assume that the currency exchange value of commodity quantity or quality reflects all the natural and social diversity of wealth. His dialectical analysis of the form of value strongly criticized the metabolic rift caused by the accumulation of labor and nature as a means of value.

\section{Marx's analysis of the natural basis of surplus-value}

Marx's discussion of physiocracy is mainly embodied in the theory of surplus-value. In his view, the generation of surplus-value does not lie in the circulation but in the production. For Marx, this "contrast with the monetary and business systems" is the first attempt to analyze the surplusvalue by using "analysis of physiocracy" [7].This also explains that the physiocracy system is the first systematic concept of capitalist production. For Marx, the source of surplus-value is the value that workers create beyond the value of labor. The productivity of the agricultural labor force is sufficient to produce more subsistence data than the agricultural laborer itself needs. Otherwise, there is no surplus-product in agriculture, and non-agricultural laborers have no livelihood, so there is no surplus-value. In his own way, Marx explained the physiocrats' puzzles because their focus on agricultural productivity was determined by their historical limitations. For farmers, agricultural labor is the only productive labor.

In view of the material needs of capital, Marx does not deny that there is a natural basis for surplus products or surplus-value, that is, the productivity of labor produced by nature. This kind of productivity produces more material than the absolute needs of workers. Natural productivity depends on its inorganic properties, such as soil quality. In evaluating physiocracy, Marx mentioned that if there is no agricultural surplus, there will be no agricultural surplus labor, and there will be no means for surviving non-agricultural workers, so there will be no surplus-value. It is noteworthy that Burkett (2006) pointed out that physiocrats, at least in agriculture, accept capitalist relations of production uncritically, attribute the determination of surplus value to nature [4].

\section{The tension based on the currency form and natural environment}

Marx insists that the market's regulation of social production itself is based on the separation of producers from the necessary production conditions. Markets and money have already existed, but the dominance of profit-driven commodity production, and the continuous pressure on producers to compete, have been attributed to the autonomous enterprises' control of the "free" labor and employment commodification. Therefore, we must turn natural conditions into production conditions that are driven only by markets and profits, and in particular labor liberated from these conditions.

The contradiction between the reduce value of capitalism to abstract labor time and the contribution of nature to the production of wealth, emphasizing the tension between the monetary form of value and the natural environment. Money is homogenous separable, mobile, and it is infinite in quantity, interlinked with changes in the quality of natural and ecological wealth. The crisis of the capitalist environment has clearly demonstrated this tension in the context of human development The basis of Marx's analysis stems from the relationship between the market value of nature and the core class relations of capitalism: the intrinsic connection between wage-labour. The quality and quantity contradiction between currency exchange value, natural real wealth and its reproduction conditions is due to the alienation of the capitalist producers relative to their living conditions. Capitalist production not only directly extracts value from the labor force but also extracts value directly from nature. The problem, however, is that this method does not systematically separate workers from these conditions, thereby regulating capital's appropriation of natural conditions, nor can it be unified into dissimilated forms, such as wage labor and capital. 


\section{E. Marx criticized ecological assessment methodology}

Ecological socialists try to attribute value directly to nature. Vegard Skirbekk (1994) believes that the looting of natural resources is limited and cannot be demanded indefinitely, otherwise it will cause poverty for future generations. [8]99 It is worth noting that he used the term "exploitation" to link value with use value.

For energy value theory, "embodied energy" is the main input resource that can explain the relative and total production costs of commodities besides measure the true source of economic value as a currency. Market valuation is assumed to be a qualitative and quantitative measure of the real resource costs of production. The uncritical attitude of physiocracy to natural marketization is reflected in their misunderstanding of the neoclassical utility theory and the ambiguity of the correspondence between market prices and individual subjective evaluations of nature. Technical pessimists are skeptical about the natural constraints faced by new technologies to overcome economic growth when they consider the value of the energy school.

Accordingly, the eco-Sraffian approach tends to capitalize on the naturalization of monetary valuations, and attributes the fact that natural resource markets are missing or incomplete to environmental issues [9]. The limitations of evaluation methods is that the Sraffian input-output model cannot distinguish qualitatively the exploitation of labor from the exploitation of other inputs. They see production as a combination of discrete factors linked by given technical parameters, and thus cannot capture capitalist specific exploitative relations: wage-labor. Therefore, these models cannot be used to construct a critical perspective on the natural assessment of specific forms of capitalism.

\section{CONCLUSION}

Marx and physiocrats pay attention to ecological and economic values. The physiocracy value theory integrates the positions held by ecological economists, emphasizing the concept of nature's gift and the natural foundational thought of surplus-value, on this basis, using some concepts of capitalism to discuss it. However, the Physiocrats did not delve into the intrinsic relationship between the capitalist relations of production and capitalist values. Nor did they critically address the problems associated with the marketization and monetization of general wealth and natural wealth. This failure can be said to be due to the fact that the physiocrats did not explore the internal connection between capitalist production relations and capitalist values.

Marx's critique of physiocracy contains a strong ecological criticism of capitalism's valuation of natural wealth. It highlights the contradiction between the reduction of the value of capitalism to the abstract labor time and the contribution of nature to the production of wealth. It also emphasizes the tension between the monetary form of value and the natural environment. From the Marx's view, capitalism regards money as homogeneous, fluid, and quantitatively infinite, which is contrary to the quantitative limitation of ecological wealth. The capitalist environmental crisis- crisis in capital accumulation and crisis in human development- clearly demonstrates this tension.

The basis of Marx's analysis stems from the inherent connection between the market value of nature and the core class relationship of capitalism, that is, wage-labor. On this basis, the contradiction of quality and quantity between the currency exchange value and natural value and reproduction conditions is attributed to the alienation of capitalist producers relative to their living conditions. Therefore, Burkett, from Marx's view, proposed to transform the alienation of capitalist natural assessment into a fit for human beings, including other species, a social form that develops with their environment. [10] It seems that only through the true social commonality can people control their social conditions of existence, instead of placing them under exploitative and non-governmental competition. On this basis, society will be able to regulate the metabolic exchange with nature in a healthy and sustainable manner. Based on the understanding of the limited nature of the historical characteristics of capitalism, this combination of producer and production conditions makes Marx's vision for natural assessment more forward-looking and scientific than accepting currency, capital, and markets as permanent forms of human and natural wealth.

\section{ACKNOWLEDGEMENT}

This paper is sponsored by Projects of the National Social Science Foundation of China (15CZX014), "EEM Program's Theoretical Development and Methodological implications".

\section{REFERENCES}

[1] Costanza and Robert.Embodied energy and economic valuation [J].Science, 1980, pp.188.

[2] Georgescu-Roegen. Energy analysis and economic valuation $[\mathrm{J}]$. Southern economic Journal, 1979, pp.1025-1045.

[3] Georgescu-Roegen. Economics and Mankind's Ecological Problem [J]. US Economic Growth from, 1976(2), pp. 236.

[4] Burkett Paul. Marxism and ecological economics: toward a red and green political economy [M]. Springer, 2006, pp.17-36

[5] Turgot and Anne Robert Jacques. Reflections on the Formation and Distribution of Riches [M].Macmillan, 1898, pp. 46.

[6] Foster J B. Marx's ecology: Materialism and nature [M]. NYU Press, 2000, pp.57.

[7] Karl Marx and Friedrich Engels. Complete Works of Marx and Engels [M], vol. 44. Beijing: People's Publishing House, 2001, pp.237-310. (In Chinese)

[8] Skirbekk G. Ethical gradualism, beyond anthropocentrism and biocentrism [J].The Notion of Sustainability, 1994, pp.99.

[9] Kurz H D, Salvadori N. Burmeister on Sraffa and the labor theory of value: a comment [J]. Journal of Political Economy, 1987(4), pp.95.

[10] Burkett Paul. Marx and nature: A red and green perspective [M] Springer, 1999, pp.57. 